\title{
Exhaustive acute exercise-induced ER stress is attenuated in IL-6-knockout mice
}

\author{
Ana P Pinto1, Alisson L da Rocha1, Eike B Kohama1', Rafael C Gaspar², Fernando M Simabuco², \\ Fabiani G Frantz², Leandro P de Moura², José R Pauli2, Dennys E Cintra², Eduardo R Ropelle², \\ Ellen C de Freitas 4 and Adelino S R da Silva ${ }^{1,4}$
}

\begin{abstract}
1Postgraduate Program in Rehabilitation and Functional Performance, Ribeirão Preto Medical School, University of São Paulo (USP), Ribeirão Preto, São Paulo, Brazil

2Laboratory of Molecular Biology of Exercise (LaBMEx), School of Applied Sciences, University of Campinas (UNICAMP), Limeira, São Paulo, Brazil ${ }^{3}$ Department of Clinical, Toxicological, and Bromatological Analysis, Faculty of Pharmaceutical Sciences of Ribeirão Preto, University of São Paulo (USP), Ribeirão Preto, São Paulo, Brazil

${ }^{4}$ School of Physical Education and Sport of Ribeirão Preto, University of São Paulo (USP), Ribeirão Preto, São Paulo, Brazil
\end{abstract}

Correspondence should be addressed to A S R da Silva: adelinosanchez@usp.br

\begin{abstract}
The endoplasmic reticulum (ER) stress and inflammation relationship occurs at different levels and is essential for the adequate homeostatic function of cellular systems, becoming harmful when chronically engaged. Intense physical exercise enhances serum levels of interleukin 6 (IL-6). In response to a chronic exhaustive physical exercise protocol, our research group verified an increase of the IL- 6 concentration and ER stress proteins in extensor digitorium longus (EDL) and soleus. Based on these results, we hypothesized that IL-6-knockout mice would demonstrate a lower modulation in the ER stress proteins compared to the wild-type mice. To clarify the relationship between exercise-induced IL-6 increased and ER stress, we studied the effects of an acute exhaustive physical exercise protocol on the levels of ER stress proteins in the skeletal muscles of IL-6-knockout (KO) mice. The WT group displayed a higher exhaustion time compared to the IL-6 KO group. After $1 \mathrm{~h}$ of the acute exercise protocol, the serum levels of IL- 6 and IL-10 were enhanced in the WT group. Independent of the experimental group, the CHOP and cleaved caspase 12/total caspase 12 ratio in EDL as well as ATF6 and $\mathrm{CHOP}$ in soleus were sensitive to the acute exercise protocol. Compared to the WT group, the oscillation patterns over time of $\mathrm{BiP}$ in EDL and soleus as well as of pelF2-alpha/elF2-alpha ratio in soleus were attenuated for the IL-6 KO group. In conclusion, IL- 6 seems to be related with the ER stress homeostasis, once knockout mice presented attenuation of BiP in EDL and soleus as well as of pEiF2-alpha/EiF2-alpha ratio in soleus after the acute exhaustive physical exercise protocol.
\end{abstract}
Key Words
- acute exhaustive exercise
- ER stress
- IL-6
- cellular signaling

Journal of Endocrinology (2019) 240, 181-193

\section{Introduction}

The endoplasmic reticulum (ER) is an organelle with a fundamental role in protein and lipid biosynthesis (Ron \& Walter 2007, Eizirik et al. 2008). When the ER suffers some stress like the accumulation of recently synthesized unfolded proteins, the unfolded protein response (UPR) is activated (Eizirik et al. 2008, Deldicque et al. 2013). UPR signaling is monitored by three proteins associated with the ER membrane, the inositol-requiring enzyme 1 
(IRE1), protein kinase RNA-like endoplasmic reticulum kinase (PERK) and activating transcription factor 6 (ATF6) (Eizirik et al. 2008). These UPR members interact with inflammatory and stress signaling systems, including c-Jun N-terminal kinase (JNK), nuclear factor kB (NF-kB) and IкB kinase (IKK) pathways (Hotamisligil 2010).

UPR induction is linked to the increased expression of interleukin 6 (IL-6), interleukin 8 (IL-8) and tumor necrosis factor-alpha (TNF-alpha) (Li et al. 2005). Also, inflammatory mediators and cellular stress activations such as JNK and IKK can have a negative impact on ER function (Deng et al. 2004). The relationship between ER stress and inflammation (13) occurs at different levels (Hotamisligil 2010) and is essential for adequate function and survival of the organism, becoming harmful when chronically engaged (Hotamisligil 2010).

The practice of intense physical exercise increases plasma IL-6 concentration (Wojewoda et al. 2014, 2015). Also, IL-6 has been connected with muscle metabolism because this cytokine is released from contracting skeletal muscles (Ostrowski et al. 1998, Pedersen et al. 2001, Pedersen \& Febbraio 2008). Recently, da Rocha et al. (2017) verified that mice submitted to an intensive treadmill running protocol showed high levels of IL-1beta, IL-6 and TNF-alpha in serum and skeletal muscle samples. Also, Pereira et al. (2016) observed high levels of skeletal muscle ER stress proteins after the same chronic exercise model. To elucidate the relationship between exerciseinduced IL-6 increases and ER stress, we investigated the effects of an acute exhaustive physical exercise protocol on the levels of ER stress proteins in the skeletal muscles of IL-6 knockout mice. Considering our previous findings (da Rocha et al. 2017), we hypothesize that IL-6 knockout mice will display a lower modulation in the ER stress proteins compared to the WT mice.

\section{Materials and methods}

\section{Experimental animals}

Eight-week-old C57BL/6 mice from the Central Animal Facility of the Ribeirão Preto campus of the University of São Paulo (USP) were used for the WT group. Eightweek-old IL- $6^{-/-}$mice from the Laboratory of Molecular Immunology and Embryology, Transgenose Institute, Centre National de la Recherche Scientifique were bred onto a C57BL/6 background and used for the IL-6-knockout (KO) group. The animals were accommodated in sterile microinsulators (three animals per cage) in a ventilated rack with controlled temperature $\left(22 \pm 2^{\circ} \mathrm{C}\right)$ on a $12: 12$-h light-dark inverted cycle (light: 18:00-06:00 h, dark: 06:00-18:00 h), food (Purina chow) and water were provided ad libitum. All experimental procedures were performed according to the Brazilian College of Animal Experimentation (COBEA) and were approved by the Ethics Committee of the University of Sao Paulo ( $\mathrm{n}^{\circ}$. z2018.5.70.90.0)

\section{Incremental load test (ILT)}

For 5 days, the animals were adapted to the treadmill running (INSIGHT, Ribeirão Preto, São Paulo, Brazil) for $10 \mathrm{~min} /$ day at $3 \mathrm{~m} / \mathrm{min}$. After $48 \mathrm{~h}$ of the adaptation protocol, the ILT started at an initial intensity of $6 \mathrm{~m} / \mathrm{min}$ at $10^{\circ}$ uphill inclination with increments of $3 \mathrm{~m} / \mathrm{min}$ every 3 min until exhaustion, which was delimited when mice touched the end of the treadmill five times in $1 \mathrm{~min}$. The ILT was used to compare the exhaustive time (min) between the WT and IL-6 KO groups.

\section{Acute exhaustive physical exercise protocol}

After $48 \mathrm{~h}$ of the ILT, WT and IL-6 KO mice performed an acute exhaustive physical exercise protocol at the treadmill running with an intensity of $22 \mathrm{~m} / \mathrm{min}$ at $10^{\circ}$ uphill inclination for 90 min (Ikeda et al. 2016). When mice became exhausted without completing the entire protocol, the exhaustion time was recorded. The animals were killed before the acute exhaustive physical exercise protocol ( $n=5$ animals per group; Basal time), at $1 \mathrm{~h}(n=5$ animals per group; $1 \mathrm{~h})$ and $3 \mathrm{~h}(n=5$ animals per group; $3 \mathrm{~h}$ ) after the acute exhaustive physical exercise protocol. This acute exhaustive physical exercise protocol was selected because the serum levels of IL-6 were increased after 1 and $3 \mathrm{~h}$ compared to the baseline (Ikeda et al. 2016). Food was provided ad libitum during the entire protocol until the animals were anesthetized.

\section{Skeletal muscle extraction}

Mice were anesthetized with an intraperitoneal injection of xylazine $(10 \mathrm{mg} / \mathrm{kg}$ of body weight), and ketamine $(100 \mathrm{mg} / \mathrm{kg}$ of body weight) and the anesthesia was confirmed by loss of pedal reflexes. Based on their different fiber type composition (Armstrong \& Phelps 1984), the extensor digitorium longus (EDL) and soleus muscles were extracted and used for immunoblotting technique. Also, gastrocnemius samples were extracted and used for glycogen concentrations. Finally, after mice decapitation, blood was collected to determine serum cytokine concentrations. 


\section{Glycogen concentrations}

The gastrocnemius glycogen concentrations were determined using the method described by Dubois et al. (1956).

\section{Serum cytokine concentrations}

The serum concentrations of IL-1beta, IL-6, IL-10, IL-15 and TNF-alpha were evaluated using Luminex TM multiplex reagents according to the instructions of the manufacturer (Millipore). For the measurement of cytokines, a MILLIPLEX MAP Mouse Cytokine Panel - 5 Plex was used. Samples were collected on the Luminex MAP200 instrument and were analyzed using the 3.1 xPONENT System.

\section{Immunoblotting technique}

The immunoblotting technique was performed as previously described by our research group (da Rocha et al. 2015, 2016, Pereira et al. 2015a,b). The antibodies used were binding immunoglobulin protein (BiP; SC33757), eukaryotic initiation factor 2 alpha (eIF2-alpha; SC11386), phospho (p)-eIF2-alpha (Ser52; SC101670), beta-actin (SC517582), alpha-tubulin (SC32293), glyceraldehyde-3phosphate dehydrogenase (GAPDH; SC365062) from Santa Cruz Biotechnology; Caspase 12 (Cell2204), growth arrest and DNA damage 153 (GADD153/CHOP; Cell2895) and beta-actin (Cell4967) from Cell Signaling Technology (Cell Signaling Technology, MA, USA); ATF6 (orb129519) from Biorbyt (Biorbyt, Cambridge, UK). Routine chemical reagents were purchased from Sigma Chemical Corporation.

The transfer efficiency onto nitrocellulose membranes was verified by brief staining of the blots with the Ponceau red stain. To verify time course effects due to the inherent variability among Western blots run at different times and days, we used a calibration method (Fig. 1). Also, we performed a test in our laboratory using the same samples in two different membranes (Fig. 2). At the end of each Western blot membrane, a sample was inserted and used as an internal control (Fig. 2A). The internal control obtained in membrane 2 was divided by the internal control obtained in membrane 1 . All the Western blots from membrane 2 were divided by this factor. As described in Fig. 2B, after divided by this factor, the arbitrary units from membrane 2 were similar to membrane 1 , and no significant difference was verified, reinforcing our calibration method.

\section{Statistical analysis}

Results are expressed as the mean \pm standard error of the mean (s.e.). The Levene's test was used to verify the homogeneity of variances and the Shapiro-Wilks $W$-test

\begin{tabular}{|c|c|c|c|}
\hline Blot 1 & Blot 2 & Blot 3 & Internal control 1 \\
\hline 10 au & 15 au & 20 au & 100 au \\
\hline \multicolumn{4}{|c|}{ Membrane 2: } \\
\hline Blot 1 & Blot 2 & Blot 3 & Internal control 2 \\
\hline I 20 au & 30 au & 40 au & 200 au \\
\hline \multicolumn{4}{|c|}{ Membrane 3: } \\
\hline Blot 1 & Blot 2 & Blot 3 & Internal control 3 \\
\hline i & 7,5 au & $10 \mathrm{au}$ & 50 au \\
\hline
\end{tabular}

Therefore, the data utilized on ANOVA analysis were these:

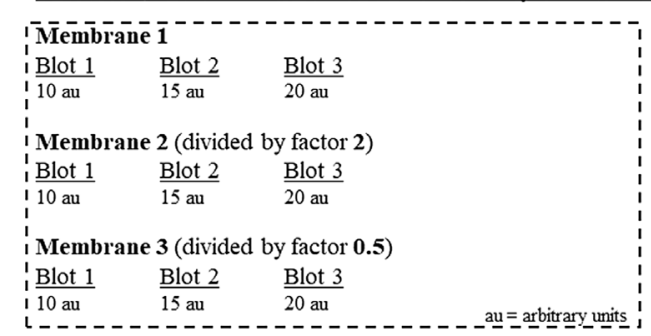

Ratio between internal control 2 and internal control 1: $200 / 100=2$

Ratio between internal control 3 and internal control 1: $50 / 100=0.5$

For membrane $2(1 \mathrm{~h})$, the calibration factor is 2 . All the blots from membrane 2 must be divide by 2 .

For membrane $3(3 \mathrm{~h})$ the calibration factor is $\mathbf{0 . 5}$. All the blots from membrane 3 must be divide by 0.5 .

Membrane 1 - Basal Time

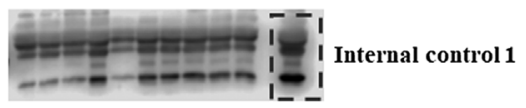

Membrane 2-1h

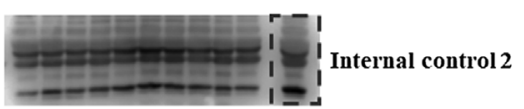

Membrane 3-3h

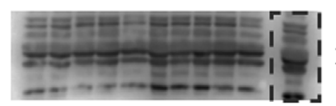

\section{Figure 1}

Western blot calibration method. Firstly, the Western blots for the same protein at the basal time, $1 \mathrm{~h}$, and $3 \mathrm{~h}$ were performed in the same tank at the same time. Nevertheless, to compare the results between these Western blots, we utilized a calibration method as follow described: At the end of each Western blot membrane, a sample was inserted and used as an internal control. The amount of protein used for this internal control was always the same. Therefore, we assumed the signals obtained after membrane revelations would be similar. When any variation occurred, we considered as an inherent variability among Western blots run in the same tank at the same time. Based on this possibility, we standardized that all experimental samples should be corrected by a calibration factor, which was obtained by the ratio between the internal controls of the different membranes. 
A
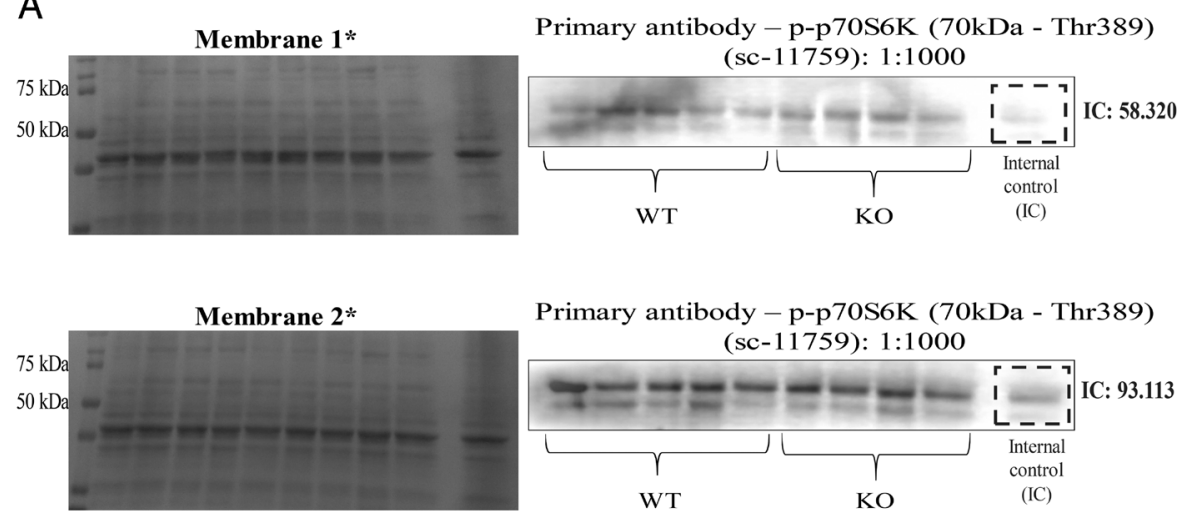

*The samples are the same in membrane 1 and membrane 2

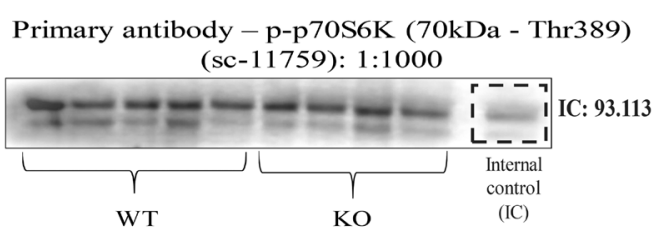

Ratio IC: $93.113 / 58.32=\underline{1.596}$

All the blots from membrane 2 were divided by factor $\underline{1.596}$

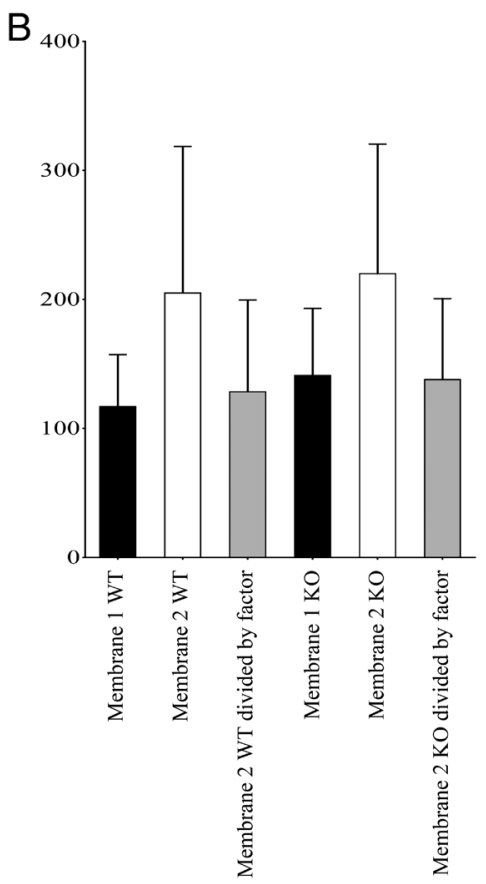

Figure 2

Internal control test. (A) Western blot test using the internal control at the end of each Western blot membrane. (B) Graph (arbitrary units).

was used to verify data normality. When normality was confirmed, the unpaired $t$-test was used for the comparison between WT and IL-6 KO groups at each time. When normality was not confirmed, the Wilcoxon test was used. When normality was confirmed, the oneway ANOVA was used for the comparison of the response of a specific protein between the evaluation times for the same group. When the normality was not confirmed, the Kruskal-Wallis test was used. All statistical analyses were set at $P<0.05$ and two sided. Statistical analyses were performed using the software SPSS v.20.0 for Windows.

\section{Results}

\section{ILT and glycogen concentrations}

Figure 3A shows that the exhaustive time (min) for the WT group $(20.0 \pm 0.74)$ was significantly higher compared to the IL-6 KO group (18.33 \pm 0.27$)$. When the glycogen concentrations were analyzed at the basal time, $1 \mathrm{~h}$ and $3 \mathrm{~h}$ after the acute exercise protocol, the IL- 6 KO group presented non-significant higher glycogen concentrations compared to the WT group (Fig. 3B).

\section{Pro- and anti-inflammatory cytokines in serum}

The serum cytokine levels of IL-1beta (Fig. 4A), IL-10 (Fig. 4C), and IL-15 (Fig. 4D) were not different between the WT and IL-6 KO groups at the basal time, $1 \mathrm{~h}$ and $3 \mathrm{~h}$ after the acute exercise protocol. For the WT group, the IL-6 levels at $1 \mathrm{~h}$ and $3 \mathrm{~h}$ after the acute exercise protocol were significantly higher compared to the basal time (Fig. 4B). For the WT and IL-6 KO groups, the IL-10 levels at $1 \mathrm{~h}$ after the acute exercise protocol were significantly
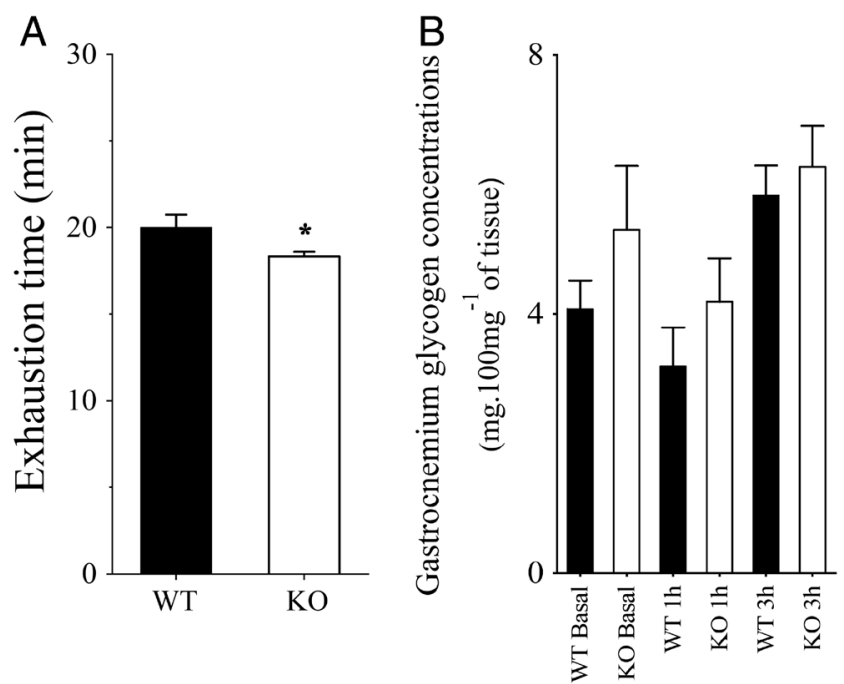

Figure 3

Exhaustion time in minutes for the WT and KO groups (A). Gastrocnemius glycogen concentrations for the WT and KO groups at the basal time, $1 \mathrm{~h}$ and $3 \mathrm{~h}$ after the acute exhaustive physical exercise protocol (B). Data correspond to means \pm S.E. of $n=30$ mice. WT, wild-type animals $(n=15)$. KO, IL-6-knockout animals $(n=15)$. ${ }^{\star} P<0.05$ vs WT group. 

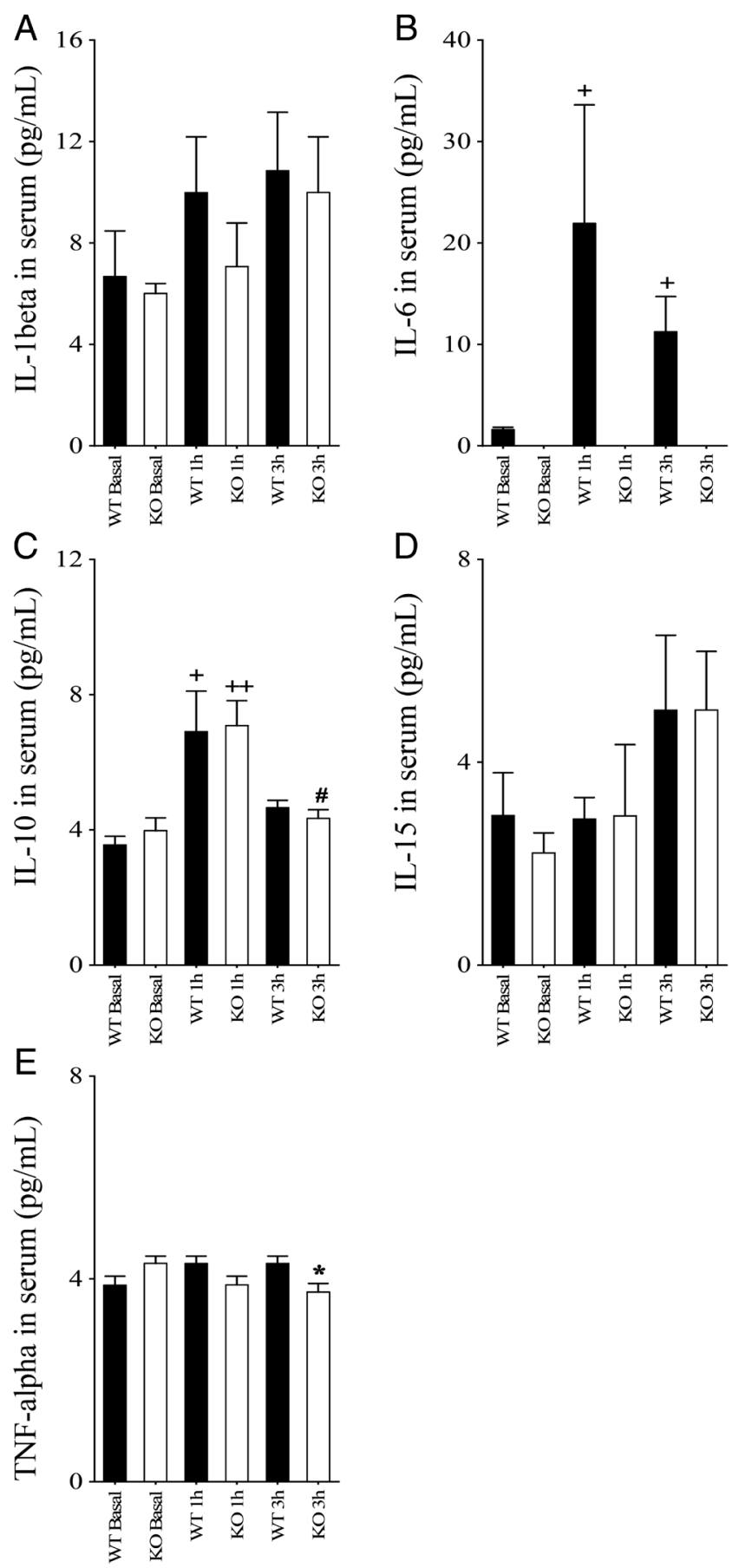

Figure 4

Serum levels (pg/mL) of IL-1 beta (A), IL-6 (B), IL-10 (C), IL-15 (D) and TNF-alpha $(\mathrm{E})$, which were measured at the basal time, $1 \mathrm{~h}$ and $3 \mathrm{~h}$ after the acute exhaustive exercise protocol for the experimental groups. Data correspond to means \pm s.E. of $n=30$ mice. WT, wild-type animals $(n=15)$. KO, IL-6 knockout animals ( $n=15)$. ${ }^{*} P<0.05$ vs WT group for the same time; ${ }^{+} P<0.05$ vs WT group at the basal time; ${ }^{++} P<0.05$ vs KO group at the basal time; $\# P<0.05$ vs KO group at $1 \mathrm{~h}$ after the acute exhaustive exercise protocol. higher compared to their respective basal times. Also, the IL-6 KO group displayed significantly higher values of IL-10 at $1 \mathrm{~h}$ compared to $3 \mathrm{~h}$ after the acute exercise protocol (Fig. 4C). The only significant difference for the TNF-alpha levels (Fig. 4E) occurred between the WT and IL-6 KO groups at $3 \mathrm{~h}$ after the acute exercise protocol.

\section{Proteins related to ER stress in EDL}

Figure $5 \mathrm{~A}$ and $\mathrm{D}$ present the protein levels of betaactin, BiP and ATF6 for the WT and IL- 6 KO groups at the basal time, $1 \mathrm{~h}$ and $3 \mathrm{~h}$ after the acute exercise protocol. The IL-6 KO group showed higher values of BiP compared to the WT group at $1 \mathrm{~h}$ after the acute exercise protocol (Fig. 5B), and ATF6 values were not different between the groups (Fig. 5E). The percentage variations of BiP and ATF6 related to the basal times for the WT and IL-6 KO groups are displayed in Fig. 5C and F, respectively.

Figure $6 \mathrm{~A}$ presents the protein levels of beta-actin, peIF2-alpha and eIF2-alpha for the WT and IL-6 KO groups at the basal time, $1 \mathrm{~h}$ and $3 \mathrm{~h}$ after the acute exercise protocol. Figure $6 \mathrm{~B}$ shows the peIF2-alpha/ eIF2-alpha ratio was not different between the WT and IL- $6 \mathrm{KO}$ groups. The percentage variations of the peIF2-alpha/eIF2-alpha ratio related to the basal times for the WT and IL-6 KO groups are displayed in Fig. 6C.

Figure 7A and $\mathrm{D}$ present the protein levels of GAPDH, CHOP, alpha-tubulin, beta-actin, total caspase 12 and cleaved caspase 12 for the WT and IL- 6 KO groups at the basal time, $1 \mathrm{~h}$ and $3 \mathrm{~h}$ after the acute exercise protocol. For the WT group, the protein levels of $\mathrm{CHOP}$ at $3 \mathrm{~h}$ after the acute exercise protocol were significantly higher compared to the basal time. For the IL- $6 \mathrm{KO}$ group, the protein levels of $\mathrm{CHOP}$ at $3 \mathrm{~h}$ were significantly higher compared to $1 \mathrm{~h}$ after the acute exercise protocol (Fig. 7B).

For the WT group, the cleaved caspase 12/total caspase 12 ratio at $3 \mathrm{~h}$ after the acute exercise protocol was significantly lower compared to the basal time. For the IL-6 KO group, the cleaved caspase 12/total caspase 12 ratios at $1 \mathrm{~h}$ and $3 \mathrm{~h}$ after the acute exercise protocol were significantly lower compared to the basal time (Fig. 7E). The percentage variations of $\mathrm{CHOP}$ and cleaved caspase $12 /$ total caspase 12 ratios related to the basal times for the WT and IL-6 KO groups are displayed in Fig. 7C and F, respectively. 
A
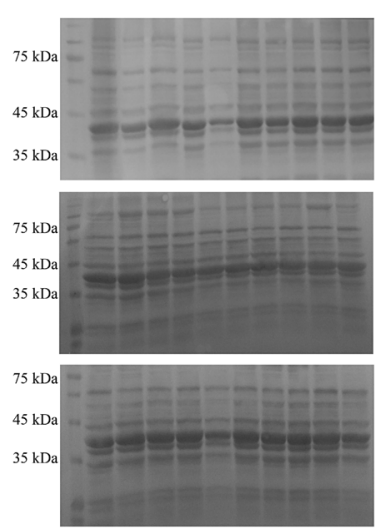

D
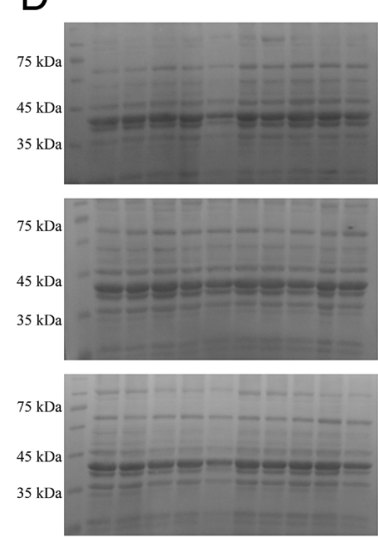

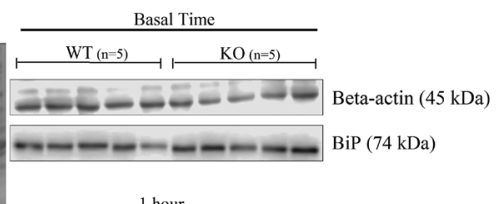

B

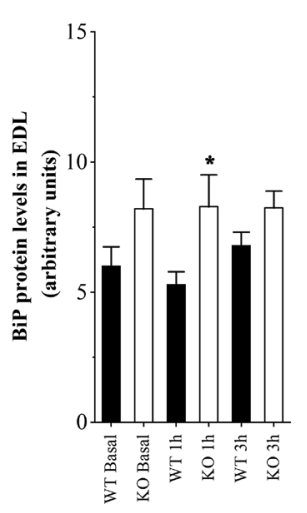

$\mathrm{E}$

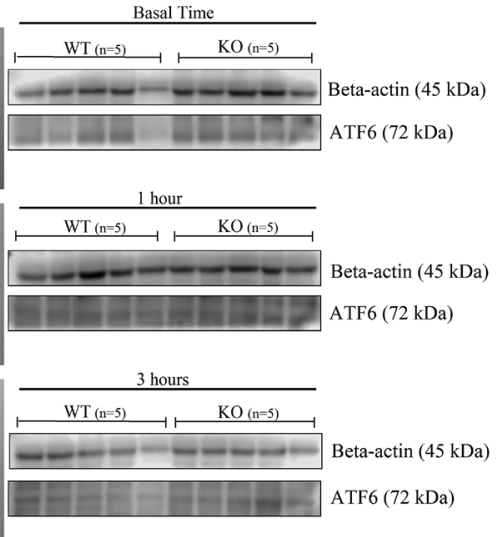

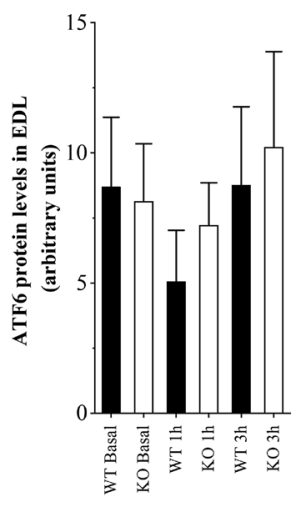

C

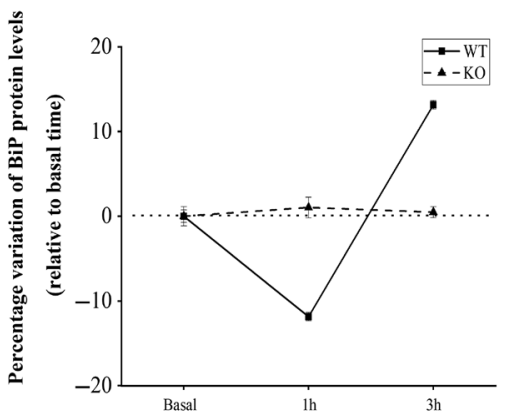

$\mathrm{F}$

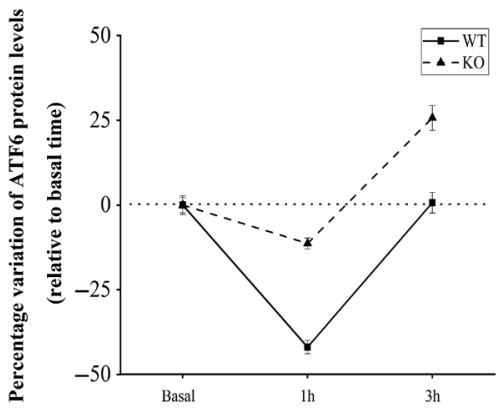

Figure 5

Protein levels (arbitrary units) in EDL of beta-actin, BiP and ATF6 (A, B, C, D, E and F), which were measured at the basal time, $1 \mathrm{~h}$ and $3 \mathrm{~h}$ after the acute exhaustive exercise protocol for the experimental groups. Data correspond to means \pm S.E. of $n=30$ mice. WT, wild-type animals ( $n=15$ ). KO, IL-6knockout animals $(n=15)$. ${ }^{*}<<0.05$ vs WT group at the same time.

\section{Proteins related to ER stress in soleus}

Figure $8 \mathrm{~A}$ and $\mathrm{D}$ present the protein levels of alphatubulin, BiP and ATF6 for the WT and IL-6 KO groups at the basal time, $1 \mathrm{~h}$ and $3 \mathrm{~h}$ after the acute exercise protocol. The IL-6 KO group showed higher values of BiP compared to the WT group at $3 \mathrm{~h}$ after the acute exercise protocol. For the IL-6 KO group, the protein levels of $\mathrm{BiP}$ at $1 \mathrm{~h}$ were significantly higher compared to $3 \mathrm{~h}$ after the acute exercise protocol. Also, the protein levels of BiP at $3 \mathrm{~h}$ after the acute exercise protocol were significantly lower compared to the basal time for the same group (Fig. 8B).

For the WT and IL-6 KO groups, the protein levels of ATF6 at $3 \mathrm{~h}$ after the acute exercise protocol were significantly lower compared to their respective basal times (Fig. 8E). The percentage variations of $\mathrm{BiP}$ and ATF6 related to the basal times for the WT and IL-6 KO groups are displayed in Fig. 8C and F, respectively. Figure 9A demonstrates the experiments of alpha-tubulin,
peIF2-alpha, eIF2-alpha and GAPDH for the WT and IL-6 KO groups at the basal time, $1 \mathrm{~h}$ and $3 \mathrm{~h}$ after the acute exercise protocol. For the WT group, the peIF2-alpha/eIF2-alpha ratio at $3 \mathrm{~h}$ after the acute exercise protocol was significantly higher compared to the basal time (Fig. 9B). The percentage variations of the peIF2-alpha/eIF2-alpha ratio related to the basal times for the WT and KO groups are displayed in Fig. 9C.

Figure $10 \mathrm{~A}$ and D present the protein levels of GAPDH, CHOP, alpha-tubulin, total caspase 12 and cleaved caspase 12 for the WT and IL- 6 KO groups at the basal time, $1 \mathrm{~h}$ and $3 \mathrm{~h}$ after the acute exercise protocol. For the WT and IL-6 KO groups, the CHOP protein levels at $1 \mathrm{~h}$ after the acute exercise protocol were significantly lower compared to their respective basal times (Fig. 10B). For the IL-6 KO group, the cleaved caspase 12/total caspase 12 ratio at $1 \mathrm{~h}$ was significantly higher compared to the basal time and $3 \mathrm{~h}$ after the acute exercise protocol. Also, the cleaved caspase 12/total caspase 12 ratio at $3 \mathrm{~h}$ after the 
A
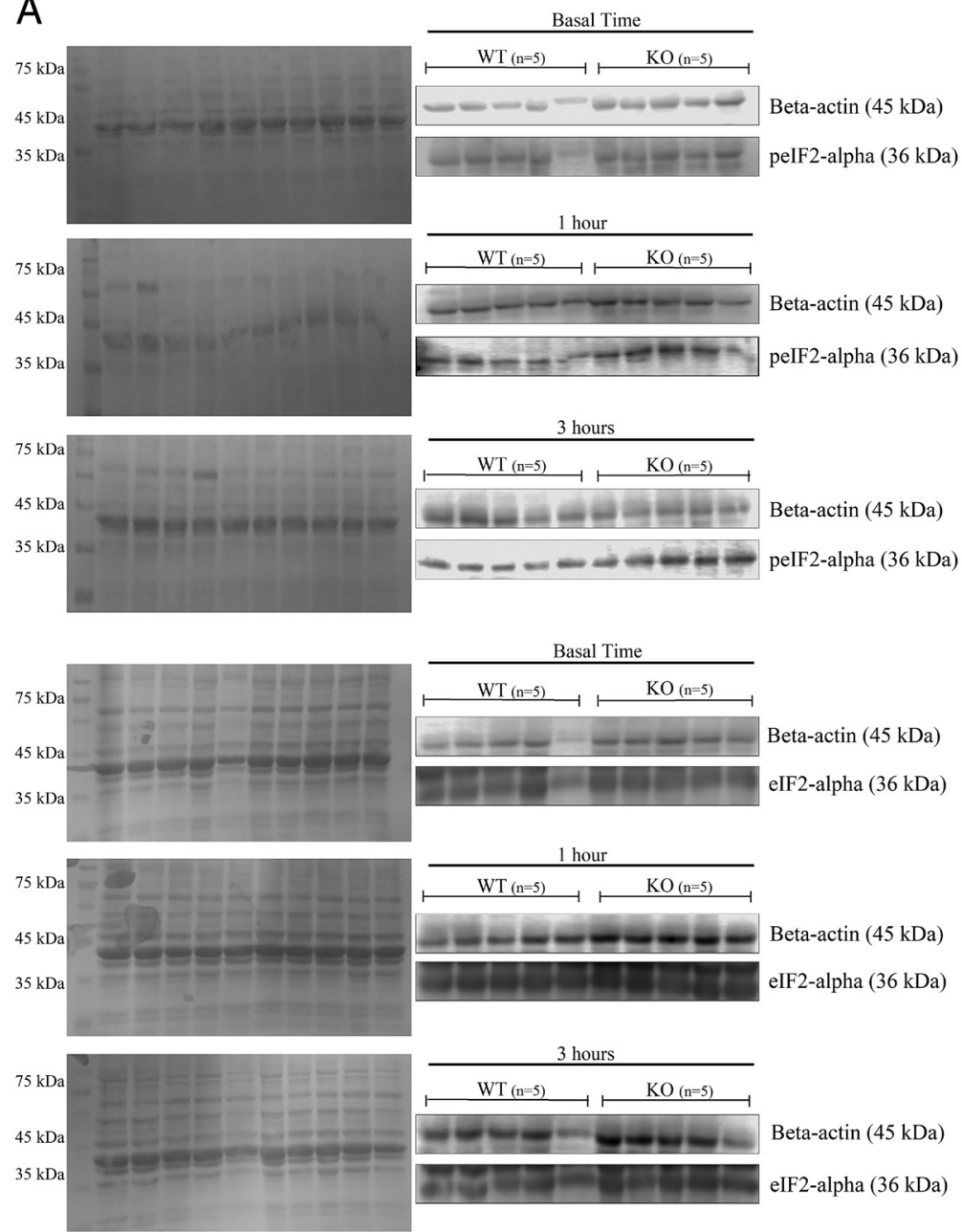

B

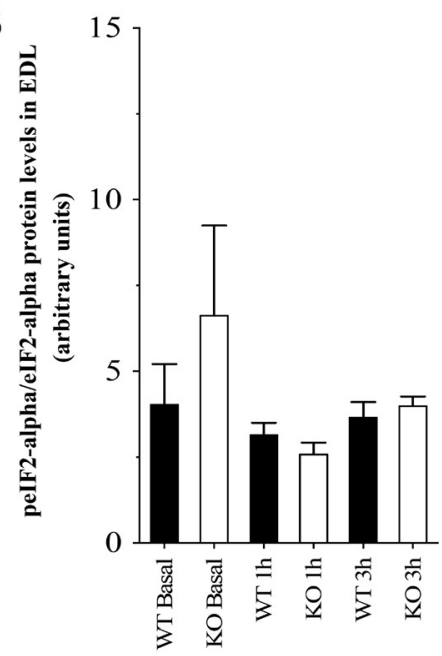

C

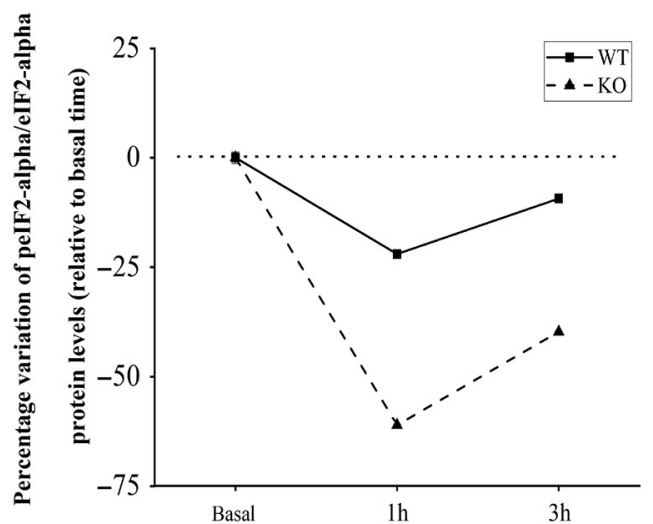

Figure 6

Protein levels (arbitrary units) in EDL of beta-actin, pelF2-alpha and eIF2-alpha (A, B and C), which were measured at the basal time, $1 \mathrm{~h}$ and $3 \mathrm{~h}$ after the acute exhaustive exercise protocol for the experimental groups. Data correspond to means \pm S.E. of $n=30$ mice. WT, wild-type animals ( $n=15$ ). KO, IL-6-knockout animals ( $n=15)$.

acute exercise protocol was significantly lower compared to the basal time (Fig. 10E). The percentage variations of $\mathrm{CHOP}$ and cleaved caspase 12/total caspase 12 ratios related to the basal times for the WT and IL- $6 \mathrm{KO}$ groups are displayed in Fig. 10C and F, respectively.

\section{Discussion}

The main findings of the present investigation were (a) the WT group showed a higher exhaustion time compared to the IL-6 KO group; (b) the two experimental groups did not exhibit significant differences for the gastrocnemius glycogen concentrations; (c) at $1 \mathrm{~h}$ after the acute exercise protocol, the serum levels of IL- 6 and IL- 10 were increased in the WT group; (d) independent of the experimental group, the protein levels of $\mathrm{CHOP}$ and cleaved caspase 12/total caspase 12 ratio in EDL as well as of ATF6 and CHOP in soleus were sensitive to the acute exercise protocol; (e) compared to the WT group, the oscillation patterns over time of BiP in EDL and soleus as well as of peIF2-alpha/eIF2-alpha ratio in soleus were blunted for the IL-6 KO group. Altogether, these findings partially support our initial hypothesis regarding IL-6 KO mice would exhibit an attenuated modulation of the ER stress proteins.

Several studies demonstrated that IL-6 KO mice had a lower exercise tolerance (Fäldt et al. 2004, Lukaszuk et al. 2012, Pedersen 2012, Wojewoda et al. 2014, 2015). After $1 \mathrm{~h}$ of running at $10 \mathrm{~m} / \mathrm{min}$ with 20 degrees of inclination, Fäldt et al. (2004) verified that IL-6 KO mice had reduced tolerance to endurance exercise. Also, Lukaszuk et al. (2012) 
A
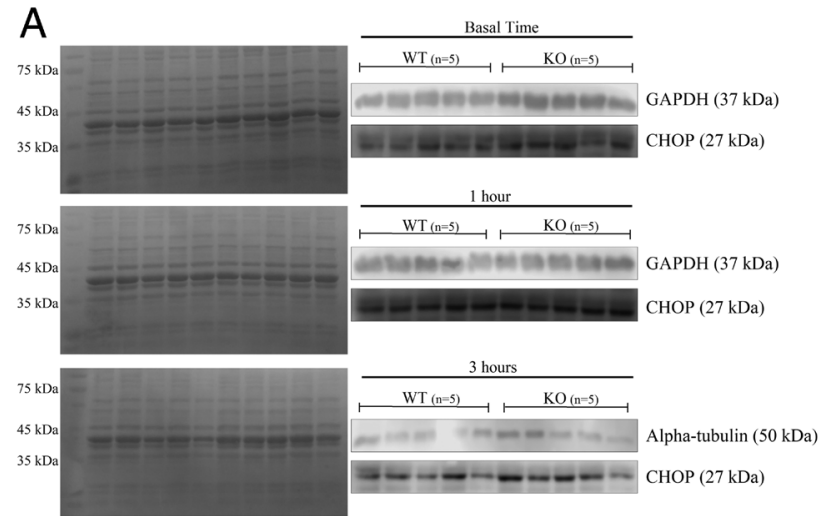

$\mathrm{D}$
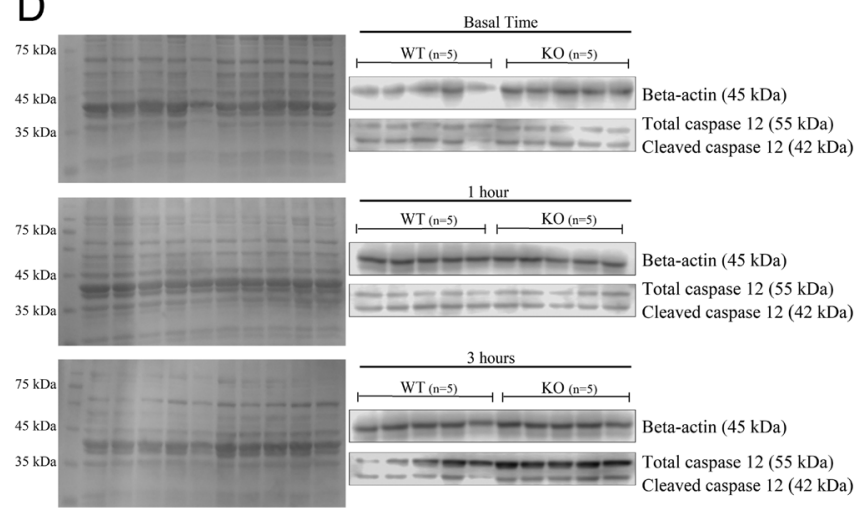

B

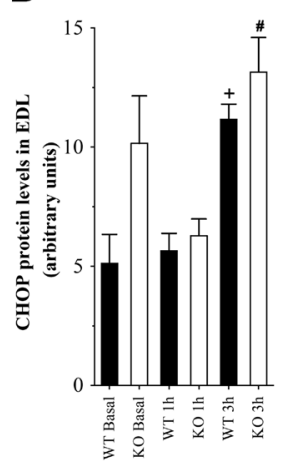

E

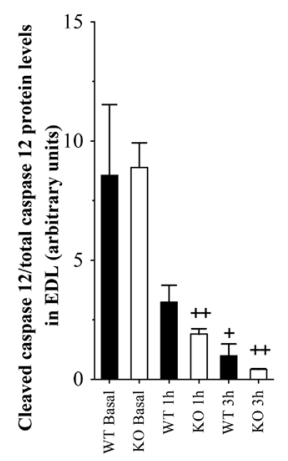

C

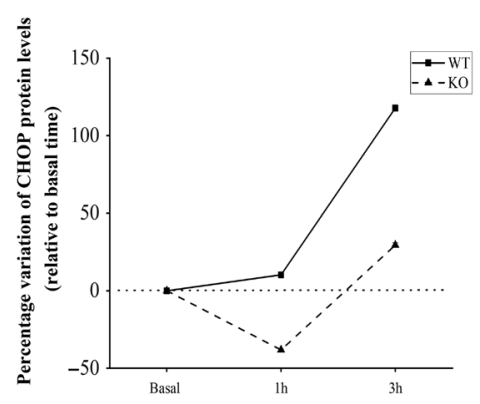

$\mathrm{F}$

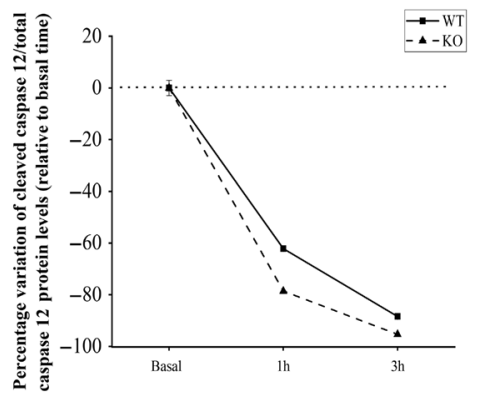

Figure 7

Protein levels (arbitrary units) in EDL of GAPDH, CHOP, alpha-tubulin, beta-actin, total caspase 12 and cleaved caspase 12 (A, B, C, D, E and F), which were measured at the basal time, $1 \mathrm{~h}$ and $3 \mathrm{~h}$ after the acute exhaustive exercise protocol for the experimental groups. Data correspond to means \pm S.E. of $n=30$ mice. WT, wild-type animals $(n=15)$. KO, IL- 6 knockout animals $(n=15) .{ }^{+} P<0.05$ vs WT group at the basal time; ${ }^{++} P<0.05$ vs KO group at the basal time; $\# P<0.05$ vs $K O$ group at $1 \mathrm{~h}$ after the acute exhaustive exercise protocol.

showed a shorter time until exhaustion in IL-6 KO mice. After chronic running exercise, Wojewoda et al. (2015) reported poor exercise tolerance of IL-6 KO mice. These results corroborate the current data in which the IL-6 KO group exhibited a shorter time until exhaustion in ILT test compared to the WT group.

The possible mechanisms responsible for these findings are not clear. One possibility could be the impairment in the heart function, leading to an inadequate cardiac output for the elevated demand for exercise, once IL-6 stimulates the sympathetic nervous system (Marz et al. 1998). Another hypothesis is a reduced skeletal muscle capillarization, limiting the transport of oxygen within the muscle and impairing the oxidative resynthesis of adenosine triphosphate (Wei et al. 2003). However, more studies are necessary to elucidate these theories.

IL-6 seems to be involved in the requirement of energy homeostasis during exercise (Pedersen 2012). Fäldt et al. (2004) did not find differences in the concentration of blood glucose, muscle glycogen and liver glycogen between IL-6-deficient and WT mice. However, Lukaszuk et al. (2012) linked the shorter time until exhaustion in IL-6 KO mice to intramuscular glycogen depletion and blood glucose alteration. According to Pedersen et al. (Steensberg et al. 2001, Keller et al. 2005), the intramuscular IL-6 mRNA expression and IL- 6 protein release are increased when intramuscular glycogen is low, indicating that IL-6 is somehow associated to glycogen content and works as an energy sensor.

A single bout of exercise increases IL-6 plasma levels in both humans and rodents (Pedersen et al. 2001, Pedersen 2012, Ikeda et al. 2016). This increase in IL-6 production is not a consequence of muscle cell damage or infiltration of immune cells but is a physiological response to moderate exercise. The IL- 6 increases during exercise and the peak is reached at the end of the exercise, returning to basal levels within hours (Ostrowski et al. 1998, 2001, Fäldt et al. 2004). Here, we verified a nonsignificant decrease of glycogen concentration and a significant increase of serum IL-6 in WT group compared 
A
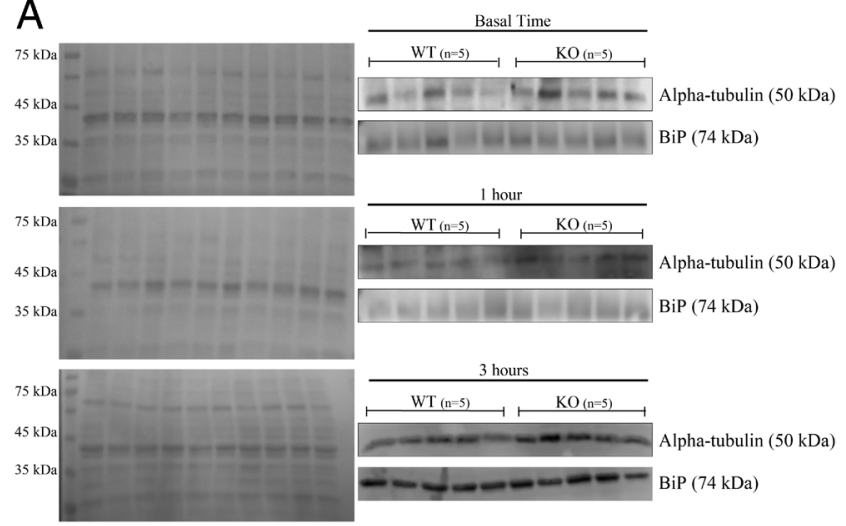

D
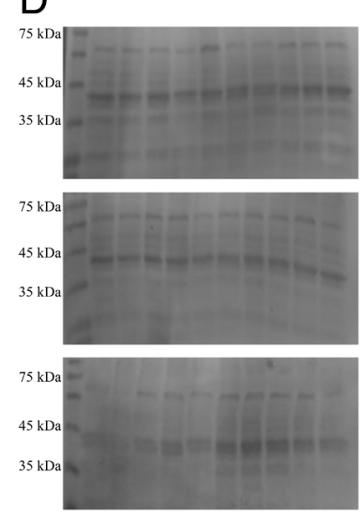
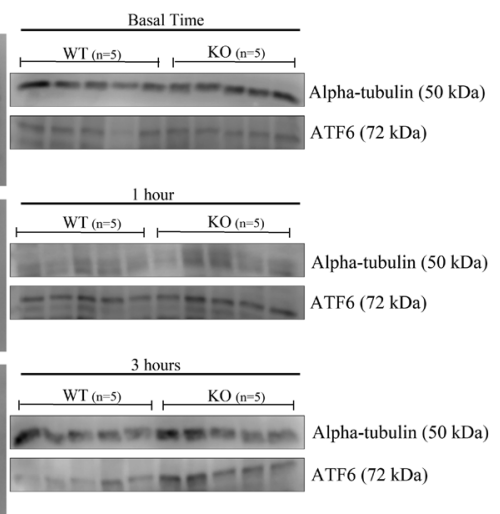

B

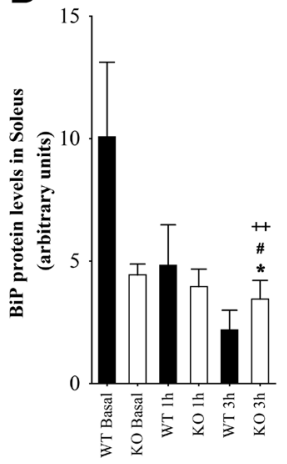

E

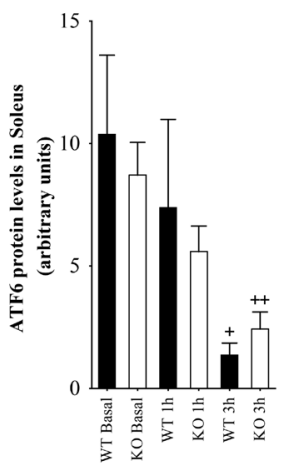

C

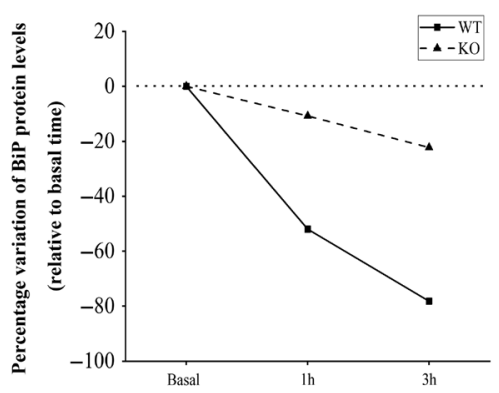

F

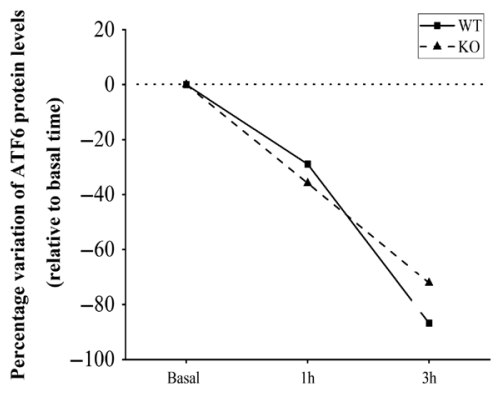

Figure 8

Protein levels (arbitrary units) in soleus of alpha-tubulin, BiP and ATF6 (A, B, C, D, E and F), which were measured at the basal time, $1 \mathrm{~h}$ and $3 \mathrm{~h}$ after the acute exhaustive exercise protocol for the experimental groups. Data correspond to means \pm S.E. of $n=30$ mice. WT, wild-type animals ( $n=15$ ). KO, IL-6-knockout animals $(n=15)$. ${ }^{*} P<0.05$ vs WT group at the same time; ${ }^{+} P<0.05$ vs WT group at the basal time; ${ }^{++} P<0.05$ vs KO group at the basal time; $\# P<0.05$ vs KO group at $1 \mathrm{~h}$ after the acute exhaustive exercise protocol.

to IL-6 KO group at $1 \mathrm{~h}$ after the acute exhaustive exercise protocol.

The magnitude of IL-6 levels is dependent on the intensity and duration of the exercise. This increase in IL-6 is accompanied by the increase of IL-1 receptor antagonist and the anti-inflammatory cytokine IL-10. Also, in response to moderate exercise, the TNF-alpha levels are not increased (Pedersen et al. 2001, Steensberg et al. 2003, Pedersen 2012). In the present study, the results corroborate the scientific literature, because after $1 \mathrm{~h}$ of exercise the animals showed an increase in IL-6 (except the IL-6 KO group) and IL-10 as well as stabilization in TNF-alpha. Also, the IL-6 levels started to decrease $3 \mathrm{~h}$ after the exercise protocol for the WT group.

The relationship between inflammation and ER stress occurs at different levels and is crucial for the adequate function and survival of the organism, becoming harmful when chronically engaged (Hotamisligil 2010). Pathways of ER stress, inflammation and oxidative stress are interdependent (Ost et al. 2016). After a chronic exhaustive physical exercise protocol, our research group showed upregulation of the IL- 6 content and ER stress proteins in both EDL and soleus (Pereira et al. 2016, da Rocha et al. 2017). Here, we investigated the relationship of exerciseinduced IL-6 increase with ER stress in different skeletal muscle samples.

The proteins related to ER stress in EDL were not different between the WT and IL- 6 KO groups at the basal time. At $1 \mathrm{~h}$ after the acute exercise protocol, the BiP protein levels were higher for the IL-6 KO group compared to the WT group (Fig. 5B). The overexpression of $\mathrm{BiP}$ is linked to the UPR signaling downregulation and PERK and IRE1 activation attenuations (Bertolotti et al. 2000, Gardner et al. 2013). Also, compared to the WT group, the oscillation pattern of BiP over time was blunted for the IL-6 KO group (Fig. 5C).

For both groups, the CHOP and cleaved caspase $12 /$ total caspase 12 protein ratio reached the maximum and minimum values, respectively, at $3 \mathrm{~h}$ after the acute exercise protocol. The link between ER stress and CHOP 
A
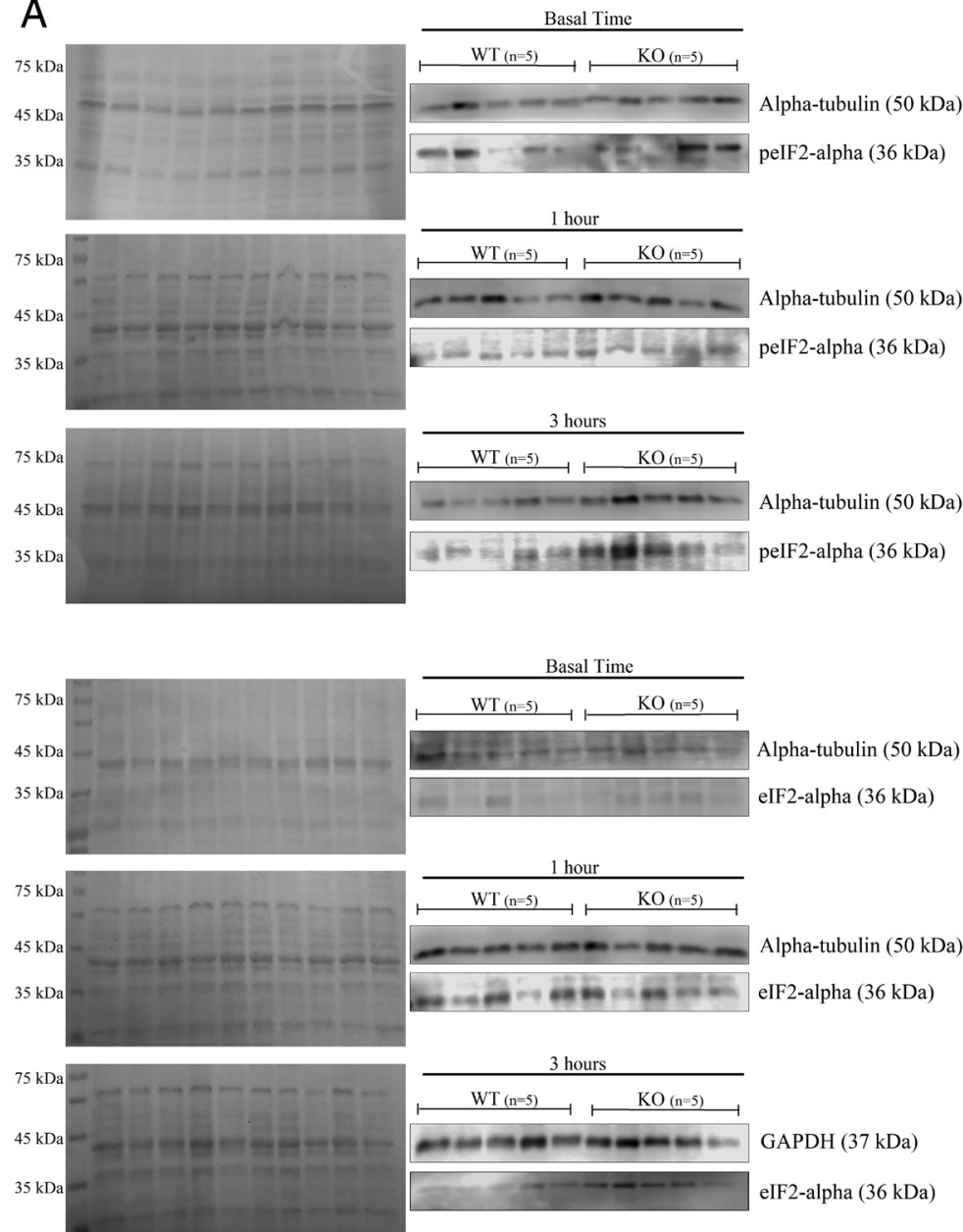

GAPDH (37 kDa)

eIF2-alpha (36 kDa)
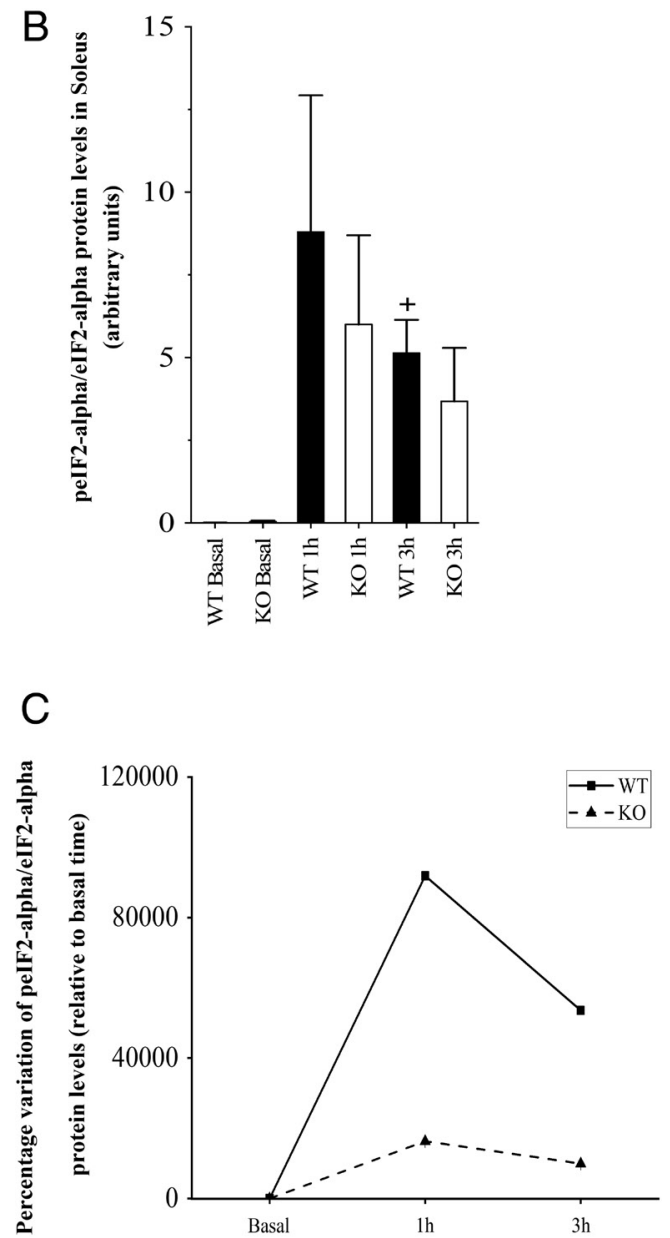

\section{Figure 9}

Protein levels (arbitrary units) in soleus of alpha-tubulin, peIF2-alpha, elF2-alpha and GAPDH, ( $\mathrm{A}, \mathrm{B}$ and $\mathrm{C})$, which were measured at the basal time, $1 \mathrm{~h}$ and $3 \mathrm{~h}$ after the acute exhaustive exercise protocol for the experimental groups. Data correspond to means \pm s.E. of $n=30$ mice. WT, wild-type animals $(n=15)$. KO, IL-6-knockout animals $(n=15) .{ }^{+} P<0.05$ vs WT group at the basal time.

expression and activation could have a role in eliciting cellular responses to ER stress-associated perturbations (Zinszner et al. 1998, Malhi \& Kaufman 2011). The overexpression of CHOP does not result in apoptosis, but may sensitize cells to apoptosis and is capable of inducing growth arrest in cycling cells (Barone et al. 1994). Caspase $12 \mathrm{KO}$ mice are resistant to ER stress-induced apoptosis but are sensitive to other death stimuli (Nakagawa et al. 2000). Except for BiP (Fig. 5C), the other proteins linked to ER stress in EDL displayed similar behavior pattern over time for the WT and IL-6 KO groups (Figs 5F, 6C, 7C and F).

Compared to EDL (Figs 5C, F, 6C, 7C and F), the oscillation patterns of BiP, ATF6, peIF2-alpha/eIF2-alpha ratio, $\mathrm{CHOP}$ and cleaved caspase 12/total caspase 12 ratio over time for the WT and IL-6 KO groups were visually different in soleus (Figs 8C, F, 9C, 10C and F). These findings may be related to the differences in muscle fiber type predominance and recruitment during the acute exhaustive physical exercise protocol for EDL and soleus.

Three hours after the acute exercise protocol, the IL- 6 KO group exhibited significantly higher values of BiP compared to the WT group (Fig. 8B). For the WT group, the peIF2-alpha/eIF2-alpha ratio reached the significant value after $3 \mathrm{~h}$ of the acute exercise protocol (Fig. 9B). The increase of peIF2-alpha/eIF2-alpha ratio is related to the impairment of translation initiation and protein synthesis (Koumenis et al. 2002, Ron \& Walter 2007). Compared to the WT group, the response of this protein to the acute exercise protocol was attenuated in the IL- 6 KO group (Fig. 9C).

Interestingly, the WT and IL-6 KO groups presented their significant lowest values of CHOP after $1 \mathrm{~h}$ of the acute exercise protocol (Fig. 10B). For the IL-6 KO group, the cleaved caspase 12/total caspase 12 ratio reached 
A
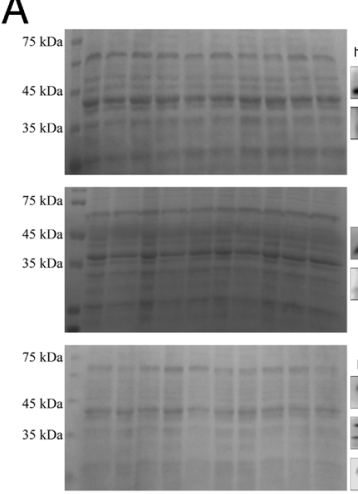

D

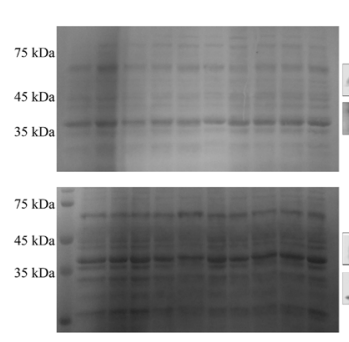

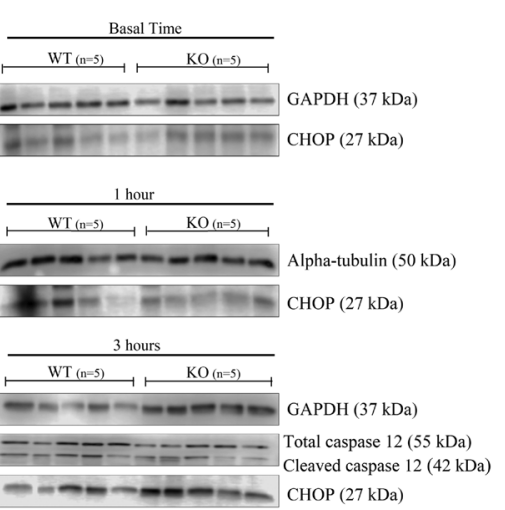
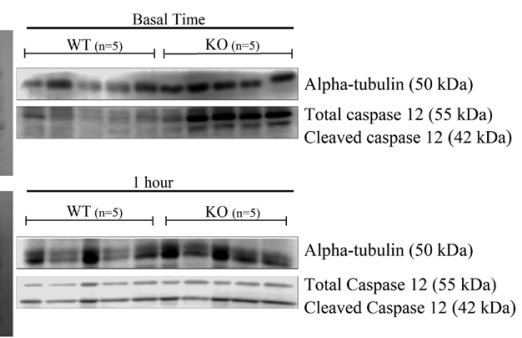

B
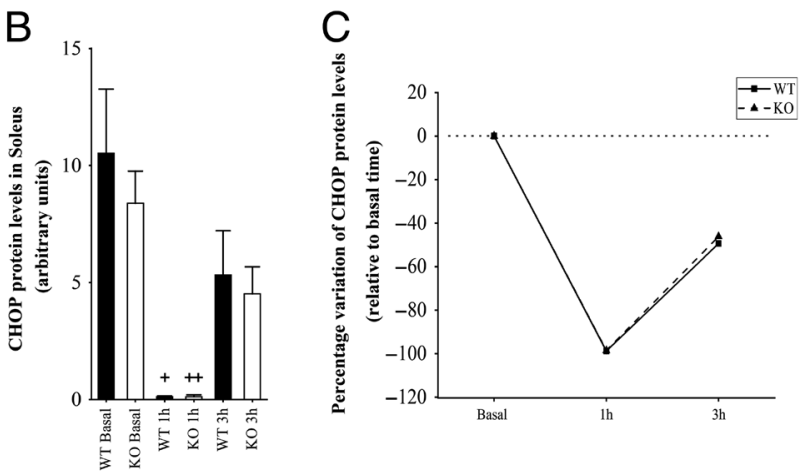

E

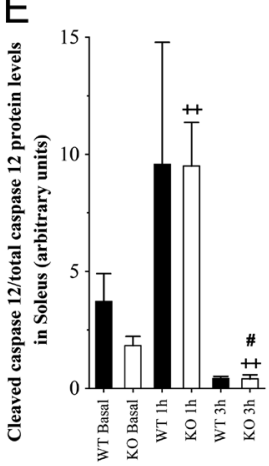

F

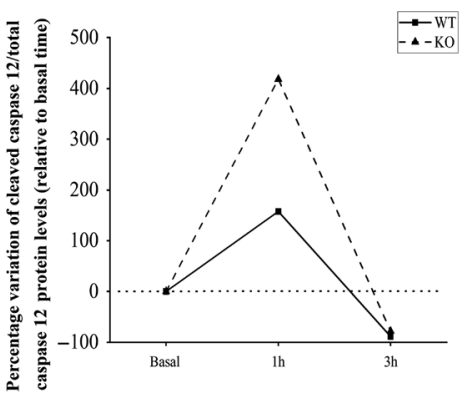

Figure 10

Protein levels (arbitrary units) in soleus of GAPDH, CHOP, alpha-tubulin, total caspase 12 and cleaved caspase 12 (A, B, C, D, E and F), which were measured at the basal time, $1 \mathrm{~h}$ and $3 \mathrm{~h}$ after the acute exhaustive exercise protocol for the experimental groups. Data correspond to means \pm s.E. of $n=30$ mice. WT, wild-type animals $(n=15)$. KO, IL- 6 knockout animals $(n=15) .{ }^{++} P<0.05$ vs KO group at the basal time; $\# P<0.05$ vs KO group at $1 \mathrm{~h}$ after the acute exhaustive exercise protocol.

the peak and bottom levels at 1 and $3 \mathrm{~h}$ after the acute exercise protocol, respectively (Fig. 10E). Except for BiP and peIF2-alpha/eIF2-alpha ratio (Figs $8 \mathrm{C}$ and 9C), the other proteins linked to ER stress in soleus displayed similar oscillation pattern over time for the WT and IL-6 KO groups (Figs $8 \mathrm{~F}$ and 10C, F).
The KO group displayed a higher peak of cleaved caspase-12 in soleus compared to the WT group. Primarily, caspase-12 was proposed to be crucial for endoplasmic reticulum (ER) stress-induced apoptosis (Nakagawa et al. 2000). However, other studies have contested this theory (Kalai et al. 2003, Saleh et al. 2006). Recently, caspase-12 was

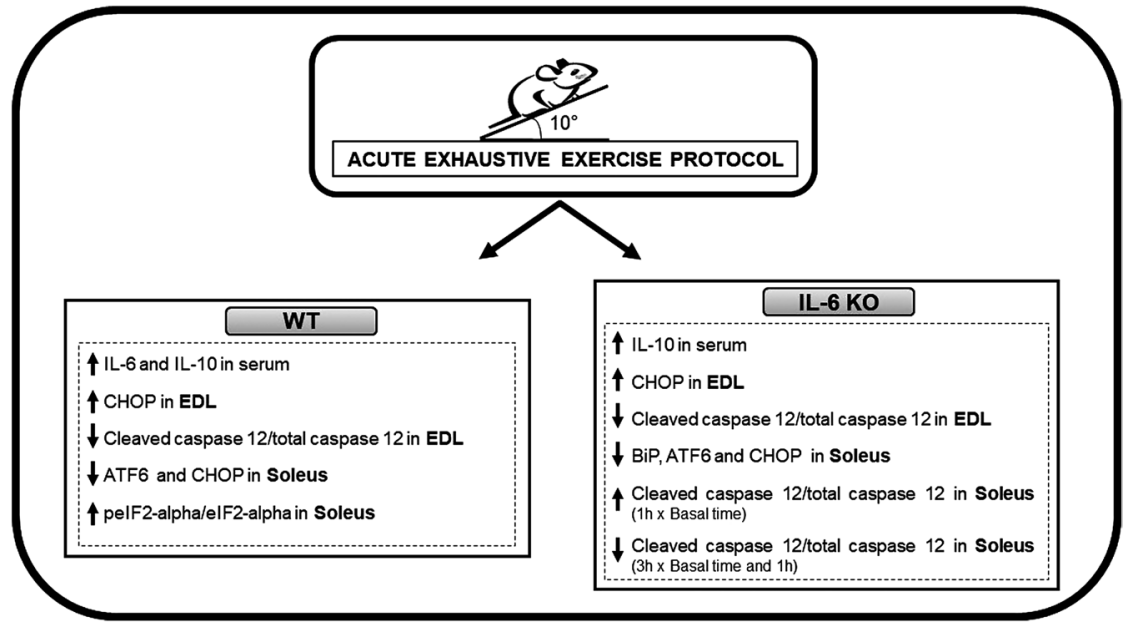

https://joe.bioscientifica.com https://doi.org/10.1530/JOE-18-0404
(C) 2019 Society for Endocrinology Published by Bioscientifica Ltd. Printed in Great Britain

\section{Figure 11}

Schematic figure summarizing the findings of the present investigation. 
suggested to negatively regulate inflammatory pathway (Fernández \& Lamkanfi 2015, Cadena \& Massieu 2016). The caspases can be classified as apoptotic (caspases-2, $-3,-6,-7,-8,-9$ and -10 ) and inflammatory (caspases-1, $-4,-5,-11$ and -12 ). Caspase-12 is accepted as a negative regulator of the inflammatory response, once it inhibits the activation of caspase- 1 in inflammasome complexes, controlling the production of IL-1b and IL-18 (Fernández \& Lamkanfi 2015, Cadena \& Massieu 2016). Also, caspase-12 modulates other inflammatory pathways, apart from the inflammasome and caspase- 1 activation through the nucleotide-binding oligomerization domain (NOD) signaling pathway (LeBlanc et al. 2008, Labbé et al. 2010).

Caspase-12 also acts as a direct inhibitor of NF-kB by interfering with the formation of IKK complex. Caspase-12 competes with an NF-kB essential modulator (NEMO) for IKK-a/b binding dislocating NEMO from the complex and preventing the subsequent degradation of IkB and NF-kB translocation (Fernández \& Lamkanfi 2015, Cadena \& Massieu 2016). In summary, caspase-12 seems to take a diverse set of molecular mechanisms to modulate innate immune signaling. Therefore, the lack of IL-6 may affect inflammatory markers.

To date, this is the first investigation describing the relationship of acute exhaustive exercise protocolinduced IL-6 increase with ER stress in different skeletal muscle samples. In conclusion, IL-6 seems to be related with the ER stress homeostasis, once IL-6 knockout animals presented attenuation of BiP in EDL and soleus as well as of peIF2-alpha/eIF2-alpha ratio in soleus after the acute exhaustive physical exercise protocol. Figure 11 summarizes the findings of the present study.

\section{Declaration of interest}

The authors declare that there is no conflict of interest that could be perceived as prejudicing the impartiality of the research reported.

\section{Funding}

The present work received financial support from the São Paulo Research Foundation (FAPESP; process numbers 2012/13558-7, 2017/09038-1, 2017/12765-2 and 2017/19869-8) and National Council for Scientific and Technological Development (CNPq; process number 309339/2016-2)

\section{Author contribution statement}

A P P, A L R and A S R S conceived and designed the experiments. A P P, $A L R, E B K, R C G, F M S$ and F G F performed the experiments. A P P and A S R S analyzed the data. F M S, F G F, L P M, J R P, D E C, ER R, E C F and A S R S contributed reagents/materials/analysis tools. A P P and A S R S wrote the paper.

(C) 2019 Society for Endocrinology Published by Bioscientifica Ltd. Printed in Great Britain

\section{References}

Armstrong RB \& Phelps RO 1984 Muscle fiber type composition of the rat hindlimb. American Journal of Anatomy 171 259-272. (https://doi org/10.1002/aja.1001710303)

Barone MV, Crozat A, Tabaee A, Philipson L \& Ron D 1994 CHOP (GADD153) and its oncogenic variant, TLS-CHOP, have opposing effects on the induction of G1/S arrest. Genes and Development $\mathbf{8}$ 453-464. (https://doi.org/10.1101/gad.8.4.453)

Bertolotti A, Zhang Y, Hendershot LM, Harding HP \& Ron D 2000 Dynamic interaction of BiP and ER stress transducers in the unfolded-protein response. Nature Cell Biology 2 326-332. (https://doi. org/10.1038/35014014)

Cadena S.G \& Massieu L 2016 Caspases and their role in inflammation and ischemic neuronal death. Focus on caspase-12. Apoptosis 21 763-777. (https://doi.org/10.1007/s10495-016-1247-0)

da Rocha AL, Pereira BC, Pauli JR, Cintra DE, de Souza CT, Ropelle ER \& da Silva AS 2015 Downhill running-based overtraining protocol improves hepatic insulin signaling pathway without concomitant decrease of inflammatory proteins. PLOS ONE 10 e0140020. (https:// doi.org/10.1371/journal.pone.0140020)

da Rocha AL, Pereira BC, Pauli JR, de Souza CT, Teixeira GR, Lira FS, Cintra DE, Ropelle ER, Junior CR \& da Silva AS 2016 Downhill running excessive training inhibits hypertrophy in mice skeletal muscles with different fiber type composition. Journal of Cellular Physiology 231 1045-1056. (https://doi.org/10.1002/jcp.25197)

da Rocha AL, Pereira BC, Teixeira GR, Pinto AP, Frantz FG, Elias LL, Lira FS, Pauli JR, Cintra DE, Ropelle ER, et al. 2017 Treadmill slope influences inflammation, changes in the fiber composition, as well as androgen and glucocorticoid receptor expressions in the skeletal muscle of overtrained mice. Frontiers in Immunology 8 1378. (https:// doi.org/10.3389/fimmu.2017.01378)

Deldicque L, Cani PD, Delzenne NM, Baar K \& Francaux M 2013 Endurance training in mice increases the unfolded protein response induced by a high-fat diet. Journal of Physiology and Biochemistry 69 215-225. (https://doi.org/10.1007/s13105-012-0204-9)

Deng J, Lu PD, Zhang Y, Scheuner D, Kaufman RJ, Sonenberg N, Harding HP \& Ron D 2004 Translational repression mediates activation of nuclear factor kappa B by phosphorylated translation initiation factor 2. Molecular and Cellular Biology 24 10161-10168. (https://doi.org/10.1128/MCB.24.23.10161-10168.2004)

Dubois M, Gilles KA, Hamilton JK, Rebers PA \& Smith F. 1956 Colorimetric method for determination of sugar and related substances. Analytical Chemistry 28 350-356. (https://doi.org/10.1021/ac60111a017)

Eizirik DL, Cardozo AK \& Cnop M 2008 The role for endoplasmic reticulum stress in diabetes mellitus. Endocrine Reviews 29 42-61. (https://doi.org/10.1210/er.2007-0015)

Fäldt J, Wernstedt I, Fitzgerald SM, Wallenius K, Bergström G \& Jansson JO 2004 Reduced exercise endurance in interleukin6-deficient mice. Endocrinology 145 2680-2686. (https://doi. org/10.1210/en.2003-1319)

Fernández DJ \& Lamkanfi M. 2015 Inflammatory caspases: key regulators of inflammation and cell death. Biological Chemistry 396 193-203. (https://doi.org/10.1515/hsz-2014-0253)

Gardner BM, Pincus D, Gotthardt K, Gallagher CM \& Walter P 2013 Endoplasmic reticulum stress sensing in the unfolded protein response. Cold Spring Harbor Perspectives in Biology 5 a013169. (https:// doi.org/10.1101/cshperspect.a013169)

Hotamisligil GS 2010 Endoplasmic reticulum stress and the inflammatory basis of metabolic disease. Cell 140 900-917. (https://doi. org/10.1016/j.cell.2010.02.034)

Ikeda SI, Tamura Y, Kakehi S, Sanada H, Kawamori R \& Watada H 2016 Exercise-induced increase in IL-6 level enhances GLUT4 expression and insulin sensitivity in mouse skeletal muscle. Biochemical and Biophysical Research Communications 473 947-952. (https://doi. org/10.1016/j.bbrc.2016.03.159) 
Kalai M, Lamkanfi M, Denecker G, Boogmans M, Lippens S, Meeus A, Declercq W, \& Vandenabeele P 2003 Regulation of the expression and processing of caspase-12. Journal of Biological Chemistry 162 457-467. (https://doi.org/10.1083/jcb.200303157)

Keller C, Steensberg A, Hansen AK, Fischer CP, Plomgaard P \& Pedersen BK 2005 Effect of exercise, training, and glycogen availability on IL-6 receptor expression in human skeletal muscle. Journal of Applied Physiology 99 2075-2079. (https://doi.org/10.1152/ japplphysiol.00590.2005)

Koumenis C, Naczki C, Koritzinsky M, Rastani S, Diehl A, Sonenberg N, Koromilas A \& Wouters BG 2002 Regulation of protein synthesis by hypoxia via activation of the endoplasmic reticulum kinase PERK and phosphorylation of the translation initiation factor eIF2 alpha. Molecular and Cellular Biology 22 7405-7416. (https://doi.org/10.1128/ MCB.22.21.7405-7416.2002)

Labbé K, Miu J, Yeretssian G, Serghides L, Tam M, Finney CA, Erdman LK, Goulet ML, Kain KC, Stevenson MM, et al. 2010 Caspase-12 dampens the immune response to malaria independently of the inflammasome by targeting NF-kB signaling. Journal of Immunology 185 5495-5502. (https://doi.org/10.4049/jimmunol.1002517)

LeBlanc PM, Yeretssian G, Rutherford N, Doiron K, Nadiri A, Zhu L, Green DR, Gruenheid S \& Saleh M 2008 Caspase-12 modulates NOD signaling and regulates antimicrobial peptide production and mucosal immunity. Cell Host and Microbe 3 146-157. (https://doi. org/10.1016/j.chom.2008.02.004)

Li Y, Schwabe RF, DeVries-Seimon T, Yao PM, Gerbod-Giannone MC, Tall AR, Davis RJ, Flavell R, Brenner DA \& Tabas I 2005 Free cholesterol-loaded macrophages are an abundant source of tumor necrosis factor-alpha and interleukin-6: model of NF-kappaB- and map kinase-dependent inflammation in advanced atherosclerosis. Journal of Biological Chemistry 280 21763-21772. (https://doi. org/10.1074/jbc.M501759200)

Lukaszuk B, Bialuk I, Gorski J, Zajaczkiewicz M, Winnicka MM \& Chabowski A 2012 A single bout of exercise increases the expression of glucose but not fatty acid transporters in skeletal muscle of IL-6 KO mice. Lipids 47 763-772. (https://doi.org/10.1007/s11745-0123678-x)

Malhi H \& Kaufman RJ 2011 Endoplasmic reticulum stress in liver disease. Journal of Hepatology $\mathbf{5 4}$ 795-809. (https://doi.org/10.1016/j. jhep.2010.11.005)

Nakagawa T, Zhu H, Morishima N, Li E, Xu J, Yankner BA \& Yuan J 2000 Caspase-12 mediates endoplasmic-reticulum-specific apoptosis and cytotoxicity by amyloid-beta. Nature $\mathbf{4 0 3}$ 98-103. (https://doi. org/10.1038/47513)

Ost M, Coleman V, Kasch J \& Klaus S 2016 Regulation of myokine expression: role of exercise and cellular stress. Free Radical Biology and Medicine 98 78-89. (https://doi.org/10.1016/j. freeradbiomed.2016.02.018)

Ostrowski K, Rohde T, Zacho M, Asp S \& Pedersen BK 1998 Evidence that interleukin-6 is produced in human skeletal muscle during prolonged running. Journal of Physiology $\mathbf{5 0 8}$ 949-953. (https://doi.org/10.1111/ j.1469-7793.1998.949bp.x)

Ostrowski K, Rohde T, Asp S, Schjerling P \& Pedersen BK 2001 Chemokines are elevated in plasma after strenuous exercise in humans. European Journal of Applied Physiology 84 244-245. (https:// doi.org/10.1007/s004210170012)

Pedersen BK 2012 Muscular interleukin-6 and its role as an energy sensor. Medicine and Science in Sports and Exercise 44 392-396. (https://doi. org/10.1249/MSS.0b013e31822f94ac)
Pedersen BK \& Febbraio MA 2008 Muscle as an endocrine organ: focus on muscle-derived interleukin-6. Physiological Reviews 88 1379-1406. (https://doi.org/10.1152/physrev.90100.2007)

Pedersen BK, Steensberg A, Fischer C, Keller C, Ostrowski K \& Schjerling P 2001 Exercise and cytokines with particular focus on muscle-derived IL-6. Exercise Immunology Review 7 18-31.

Pereira BC, da Rocha AL, Pauli JR, Ropelle ER, de Souza CT, Cintra DE, Sant'Ana MR \& da Silva AS 2015a Excessive eccentric exercise leads to transitory hypothalamic inflammation, which may contribute to the low body weight gain and food intake in overtrained mice. Neuroscience $\mathbf{3 1 1}$ 231-242. (https://doi.org/10.1016/j.neuroscience.2015.10.027)

Pereira BC, Lucas G, da Rocha AL, Pauli JR, Ropelle ER, Cintra D, de Souza CT, Bueno CR \& da Silva AS $2015 b$ Eccentric exercise leads to glial activation but not apoptosis in mice spinal cords. International Journal of Sports Medicine 36 378-385. (https://doi. org/10.1055/s-0034-1395589)

Pereira BC, da Rocha AL, Pinto AP, Pauli JR, de Souza CT, Cintra DE, Ropelle ER, de Freitas EC, Zagatto AM \& da Silva ASR 2016 Excessive eccentric exercise-induced overtraining model leads to endoplasmic reticulum stress in mice skeletal muscles. Life Science 145 144-151. (https://doi.org/10.1016/j.lfs.2015.12.037)

Marz P, Cheng JG, Gadient RA, Patterson PH, Stoyan T, Otten U \& Rose-John S 1998 Sympathetic neurons can produce and respond to interleukin 6. PNAS 955.

Ron D \& Walter P 2007 Signal integration in the endoplasmic reticulum unfolded protein response. Nature Reviews Molecular Cell Biology $\mathbf{8}$ 519-529. (https://doi.org/10.1038/nrm2199)

Saleh M, Mathison JC, Wolinski MK, Bensinger SJ, Fitzgerald P, Droin N, Ulevitch RJ, Green DR \& Nicholson DW 2006 Enhanced bacterial clearance and sepsis resistance in caspase-12-deficient mice. Nature 440 1064-1068. (https://doi.org/10.1038/nature04656)

Steensberg A, Febbraio MA, Osada T, Schjerling P, van Hall G, Saltin B \& Pedersen BK 2001 Interleukin-6 production in contracting human skeletal muscle is influenced by pre-exercise muscle glycogen content. Journal of Physiology 537 633-639. (https://doi.org/10.1111/j.14697793.2001.00633.x)

Steensberg A, Fischer CP, Keller C, Møller K \& Pedersen BK 2003 IL-6 enhances plasma IL-1ra, IL-10, and cortisol in humans. American Journal of Physiology: Endocrinology and Metabolism 285 E433-E437. (https://doi.org/10.1152/ajpcell.00509.2002)

Wei LH, Kuo ML, Chen CA, Chou CH, Lai KB, Lee CN \& Hsieh CY 2003 Interleukin-6 promotes cervical tumor growth by VEGF-dependent angiogenesis via a STAT3 pathway. Oncogene 22 1517-1527. (https:// doi.org/10.1038/sj.onc.1206226)

Wojewoda M, Kmiecik K, Ventura-Clapier R, Fortin D, Onopiuk M, Jakubczyk J, Sitek B, Fedorowicz A, Majerczak J, Kaminski K, et al. 2014 Running performance at high running velocities is impaired but $\mathrm{V}^{\prime} \mathrm{O}\left({ }_{2} \max \right)$ and peripheral endothelial function are preserved in IL-6-/- mice. PLoS ONE 9 e88333. (https://doi.org/10.1371/journal. pone.0088333)

Wojewoda M, Kmiecik K, Majerczak J, Ventura-Clapier R, Fortin D, Onopiuk M, Rog J, Kaminski K, Chlopicki S \& Zoladz JA 2015 Skeletal muscle response to endurance training in IL-6-/- mice. International Journal of Sports Medicine 36 1163-1169. (https://doi. org/10.1055/s-0035-1555851)

Zinszner H, Kuroda M, Wang X, Batchvarova N, Lightfoot RT, Remotti H, Stevens JL \& Ron D 1998 CHOP is implicated in programmed cell death in response to impaired function of the endoplasmic reticulum. Genes and Development 12 982-995. (https://doi.org/10.1101/gad.12.7.982)

Received in final form 18 October 2018

Accepted 26 October 2018

Accepted Preprint published online 1 November 2018 https://joe.bioscientifica.com https://doi.org/10.1530/JOE-18-0404 (c) 2019 Society for Endocrinology Published by Bioscientifica Ltd.
Printed in Great Britain 